\title{
A DYNAMIC MODEL OF PROFIT OF RESIDENTIAL PROJECTS IN VIETNAM
}

\author{
Nghia Hoai NGUYEN ${ }^{1,2,}$, Thanwadee CHINDA ${ }^{1}$ \\ ${ }^{1}$ School of Management Technology, Sirindhorn International Institute of Technology (SIIT), Thammasat \\ University, 131 Moo 5, Tivanond Road, Bangkadi Industrial Park, Bangkadi Mueang, \\ Pathum Thani 12000, Thailand \\ ${ }^{2}$ Department of Civil and Electrical Engineering, Ho Chi Minh City Open University, Room 801, 35-37 Ho Hao \\ Hon Street, District 1, Ho Chi Minh City, Vietnam
}

Received 28 May 2017; accepted 16 January 2018

\begin{abstract}
It is difficult to estimate the profit of residential projects as there are a number of complicated relationships among key profit factors. This study develops a dynamic model of the profit of residential projects in Ho Chi Minh City, Vietnam, utilizing a system dynamic approach, to examine the profit of residential projects in the long term. Five key profit factors, including the Urban Population, Buyer Capacity, Housing Supply, Housing Economics, and Housing Finance factors, are used to develop the dynamic model. Simulation results reveal that the average profit of residential projects in Ho Chi Minh City, Vietnam, in the next 20 years, is 35\%, with a minimum and maximum profit of $19 \%$ and $41 \%$, respectively. Scenario analyses recommend that a $30 \%$ down payment, a 25 -year payment period, and a debt to equity ratio of $40 \%$ are the best strategies that residential companies should use to maximize profit in the long term. It is also recommended that debt to equity ratio and house price should be maintained in the early years to assist low-income households. The developed model can be used as a starting point to develop a software that allows developers to examine strategies by simply inputting their available data.
\end{abstract}

Keywords: dynamic model, profit, residential projects, simulation, system dynamics.

\section{Introduction}

Ho Chi Minh City is the most crowded and developed city in Vietnam. The gross domestic product (GDP) of the city is about $22 \%$ of the total country GDP (the General Statistics Office of Vietnam [GSO], 2015a). Also, the GDP per capita increased from 1,232 USD/person in 2009 to $1,910 \mathrm{USD} /$ person in 2013, representing a 55\% increase rate (GSO, 2015a). The population of this city has also increased by $4.3 \%$ in the last five years (GSO, 2015a).

It is confirmed that increases in economic development and population in Ho Chi Minh City lead the city to higher housing demand, resulting in more houses supplied and transacted (see Table 1) (Gerlach \& Peng, 2005; Ho, Wang, \& Liu, 2010). This, in turn, leads real estate developers to a better opportunity to earn more profit from real estate investment. However, it is difficult to estimate profit, and establish proper policies in a dynamic business environment, as there are a number of variables influencing profit of residential projects. Some variables, such as house price, construction cost, and number of houses transacted affect profit directly, while such variables as changes in family size, economic growth, and interest rate indirectly influence profit through the implementation of other factors (Ho et al., 2010; Park, M. Lee, H. Lee, \& Hwang, 2010; Park, Kim, Lee, Han, \& Hwang, 2013). Moreover, these variables have both short and long term effects on the profit. Rehring and Sebastian (2011), for example, confirmed that housing transaction had a short term impact on house price and profitability. Ling and Naranjo (2003), on the other hand, stated that debt and equity had a long term effect on profitability. Chandler and Disney (2014) mentioned that housing supply and housing stock had both short and long term impacts on profitability.

The above variables affected profit of residential projects in various ways. An inflation rate, for example, fluctuated in the last three years, resulting in the changes in the debt to equity ratio, construction cost, and housing supply amount. To improve profit in the long term, it is

*Corresponding author. E-mail: nghianew@yahoo.com 
Table 1. Housing supply and transactions (Savills, 2015)

\begin{tabular}{|c|c|c|c|}
\hline \multirow{2}{*}{ Year } & \multicolumn{3}{|c|}{ House (unit) } \\
\cline { 2 - 4 } & New & Supplied & Transacted \\
\hline 2011 & 2,337 & 13,959 & 5,378 \\
\hline 2012 & 4,310 & 14,630 & 3,639 \\
\hline 2013 & 6,420 & 15,300 & 5,750 \\
\hline 2014 & 15,920 & 19,000 & 12,220 \\
\hline
\end{tabular}

necessary to investigate key profit variables, and examine their interactions over a period of time. This paper, therefore, aims at developing a dynamic model of the profit of residential projects in Ho Chi Minh City, Vietnam, utilizing a system dynamics modeling approach, so that the real estate industry can better plan for profit improvement in the long term. To achieve the aim, an extensive literature review is carried out to explore research gaps. A list of profit variables as well as their causal relationships is summarized to be used for a dynamic model of profit enhancement development. Secondary and primary data are then collected through journal papers, annual reports, company profiles, and personal interviews to develop a dynamic model of profit of residential projects. The model validation and simulation results are developed and a number of scenarios are conducted to examine the profit of residential projects in the long term (see Figure 1).

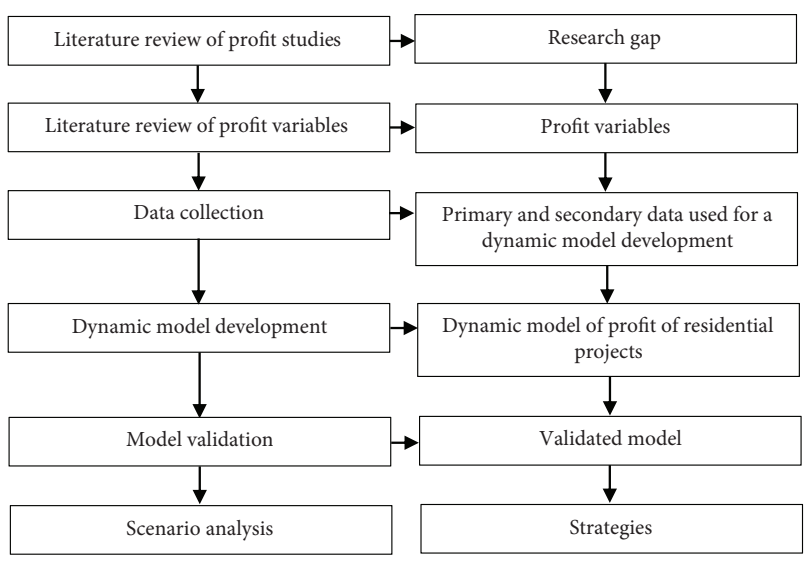

Figure 1. Research activities

\section{Previous studies}

Many researches of profitability in real estate- and construction-related studies were conducted using a regression method. Hung, Liu, and Chen (2002), for example, explored relationships among the profitability and financial attributes of the real estate and construction companies in Hong Kong using an ordinary least squares regression model. The study confirmed correlations among profit, cost of capital, and capital structure. Contractors, however, earned less profit than developers due to higher financial cost. Mahmood and Zakaria (2007) also utilized an ordinary least squares regression model to examine differences of returns among the real estate and construction companies in Malaysia. It was found that the Malaysian developers received higher profit than the construction companies due to less debt to equity ratio. Liow (2010), on the other hand, applied a simultaneous regression to examine profitability of real estate companies in Asia, Europe, and North America based on a number of financial variables, such as debt to equity ratio, cost of equity, and return on equity. It was confirmed that debt to equity negatively influenced profit in both Asian and Western countries. Tsolas (2011) used a two-step approach, including a data envelopment analysis and an ordinary least squares regression model, to examine factors of profit performance and effectiveness of the Greek listed construction firms. Results revealed that size of companies and a ratio of expenses to total revenue were key factors of profit performance. Kang and Bai (2014) examined relationships among profitability and capital structure of the Chinese real estate listed companies utilizing a factor analysis and a multiple regression model. It was concluded that equity ratio and asset turnover played important roles on profit.

In the U.S. real estate market, the regression method is also used to examine profitability. Ling and Naranjo (2003), for instance, confirmed positive relationships among capital flow and profit of the Real Estate Investment Trusts in the U.S. using a vector auto-regression method. Choi and Russell (2005) examined changes in profit of the U.S. construction companies using a 2-level regression model. Changing business portfolios was confirmed to not affect profit. Fisher, Ling, and Naranjo (2009) examined shortand long-run dynamic relationships among capital flow and returns in the U.S. private real estate market utilizing a vector auto-regression model. Results showed that capital flow had a crucial effect on profit of condominium and office properties sectors.

Apart from the regression method, the structural equation modelling, optimization algorithm, and system dynamics modelling approaches are also used in profitrelated studies. Kim and Yang (2006), for example, utilized a structural equation modeling to examine the profit of the Korean office rental market. It was found that a higher deposit with a lower monthly rent was a good strategy to enhance the profit. Liu and Wang (2008) optimized profit of the Chinese construction projects, utilizing an optimization algorithm. The study confirmed the significant effects of credit and resource limits, and construction schedule on profit of the construction projects. Gimpelevich (2011) presented a simulation model based on the Monte Carlo simulation and the discounted cash flow to help quantifying the profit of the high rise office development in the U.S. It was confirmed that equity, construction loan interest rate, project schedule, and construction cost were crucial factors of the profit. Saeed and Brooke (1996), on the other hand, developed a model based on a system dynamic (SD) approach to ensure profitability of the macro-construction projects in Asia. It was recommended that the experimental analysis affected contract 
clauses, and eliminated time and cost overruns, leading to higher profit. Hou, Liu, and Chen (2011) also applied an $\mathrm{SD}$ approach to examine profits of the Chinese construction projects, and concluded that contractors received less profit as owners delayed the payment.

Despite the above studies, it is necessary to develop a dynamic model of profit of residential projects, by examining causal relationships among profit variables, and effects of those variables on profit in the long term. The developed model should also capture multiple feedback processes among profit variables so that profit improvement can effectively be planned. This study, therefore, applied an SD methodology to develop a dynamic model to examine the profitability of residential projects in the long term due to the followings:

- It can be used to deal with behavior changes over time.

- It can be used to examine causal relationships among key profit factors.

- It can be used to evaluate profit with feedback structures.

- It can be used to examine different scenarios to select the best profit implementation plan.

- It can be used to forecast profit in the long term.

The SD modeling technique is used to simulate largescale complex systems with many factors that have complicated relationships (Zhao, Ren, \& Rotter, 2011). It is also used in evaluating different behaviors of real-world systems in the long term (Hwang, Park, H. Lee, S. Lee, \& Kim, 2013b; Doan \& Chinda, 2016). The approach is applied in many research areas. Clark and Jones (2008), for example, developed an SD model to examine the effectiveness of a management supporting system in the United States. Capelo and Dias (2009) used an SD technique to measure the learning perspective of the Portuguese student performance. Zhao et al. (2011) assessed the effectiveness of different types of the recycling centers in China, based on a number of economic factors, including profit, unit cost, and location-advantage income.

The SD modeling technique is also applied in the real estate- and construction-related literature, both in developed and developing countries. Huang and Wang (2005), for example, developed a pre-warning model to help policy makers control the Chinese property market. It was found that the GDP growth rate, ratio of building area to overall planned area, ratio of pre-sale houses, and ratio between supply and demand can be used as warning factors in the long term. Ho, Wang, and Liu (2010) also used an SD model to assist policy makers to monitor the Taiwanese real estate market. It was suggested that the Taiwanese government should fully utilize existing capacities if resources were limited. Barlas, Ozgun, and Ozbas (2007) utilized an SD model to examine effects of house price oscillations on the Turkish real estate market in the long term. It was concluded that the main reasons for price fluctuation were delays in the starting of new projects and an over-supply. Hwang, Park, and Lee (2013a) applied an SD approach to examine the effects of different govern- ment policies on loans in the Korean real estate market. It was found that the government should issue regulations on secondary lending agencies to maximize the effectiveness of the existing policies.

The SD modeling technique is used in this study to develop a dynamic model of profit of residential projects to examine the relationships of key profit factors, and effectively plan for profit enhancement in the long term.

\section{Profit factors}

As mentioned earlier, profit is affected by a number of variables. Liow (2010), for example, concluded the effect of debt to equity on profit of developers. Kwoun, Lee, J. Kim, and J. Kim (2013) confirmed a number of variables, including economic, policy, housing demand, and housing supply in improving profit. Hwang et al. (2013b) stated that housing supply, housing transaction, house price, and housing stock affected profit of developers. Barlas et al. (2007) confirmed that house price, construction cost, interest rate, housing supply, and demand influenced profit of housing developers.

Nguyen and Chinda (2018) conducted an extensive study on profit factors, focusing on five factors, including: 1) Urban Population, 2) Buyer Capacity, 3) Housing Supply, 4) Housing Economics, and 5) Housing Finance factors. A structural equation modeling approach was utilized to confirm the five profit factors and their causal relationships. The study results confirmed five key factors, together with their 16 associated variables, as having influences on the profit of residential projects (see Table 2). The Urban Population factor, for example, consists of population and number of households (Ho et al., 2010). Home ownership rate and household income variables are grouped into the Buyer Capacity factor, while housing stock, housing pre-sale, and housing transaction variables explain the Housing Supply factor (Amini, Kasmaei, Sharifan, Eslamifar, \& Aghdaei, 2013; Hwang et al., 2013a).

Table 2. Key profit factors and their associated variables (Nguyen \& Chinda, 2018)

\begin{tabular}{|c|l|l|}
\hline No. & \multicolumn{1}{|c|}{ Factor } & \multicolumn{1}{|c|}{ Variable } \\
\hline 1 & Urban population & $\begin{array}{l}\text { Population } \\
\text { Number of families }\end{array}$ \\
\hline 2 & Buyer capacity & $\begin{array}{l}\text { Household income } \\
\text { Home ownership rate }\end{array}$ \\
\hline 3 & Housing supply & $\begin{array}{l}\text { Housing stock } \\
\text { Housing presale } \\
\text { Housing transaction }\end{array}$ \\
\hline 4 & Housing economics & $\begin{array}{l}\text { House price } \\
\text { Deposit interest rate } \\
\text { Construction cost } \\
\text { Land and consultant cost } \\
\text { Taxes and fees }\end{array}$ \\
\hline 5 & Housing finance & $\begin{array}{l}\text { Housing loan interest rate } \\
\text { Construction loan interest rate } \\
\text { Debt to equity ratio } \\
\text { Payment schedule }\end{array}$ \\
\hline
\end{tabular}


The results confirmed a number of causal relationships among the five key profit factors. More households (a variable of the Urban Population factor), for example, leads to more housing loan, and higher housing loan interest rate (a variable of the Housing Finance factor). This, in turn, lowers buyer capacity (a variable of the Buyer Capacity factor), as monthly payment is increased (Amini et al., 2013). An increase in population (a variable of the Urban Population factor) leads to higher house prices (a variable of the Housing Economics factor), resulting higher profit of residential projects (Borowiecki, 2009). Fewer houses are constructed (a variable of the Housing Supply factor) when taxes (a variable of the Housing Economics factor) increase (Park et al., 2010). This leads to fewer houses purchased and owned (a variable of the Buyer Capacity factor). When more credits (a variable of the Housing Finance factor) are available, more houses are constructed (a variable of the Housing Supply factor) and purchased (a variable of the Buyer Capacity factor), resulting in more profit to developers. High debt to equity ratio (a variable of the Housing Finance factor) results in more houses supplied (a variable of the Housing Supply factor) (Morri \& Cristanziani, 2009). High housing loan interest rate (a variable of the Housing Finance factor), in contrast, leads to fewer houses owned (a variable of the Buyer Capacity factor) (Amini et al., 2013).

In this study, a dynamic model of profit of residential projects is developed based on five profit factors and their causal relationships achieved from Nguyen and Chinda (2018).

\section{Secondary and primary data}

A dynamic model of profit of residential projects is developed using secondary and primary data as model input (see Table 3). Examples of secondary data are population, home ownership rate, housing stock, and housing supply. The GSO (2015a), for example, confirmed that the population in Ho Chi Minh City in 2014 was 7,981,900 persons, with

Table 3. Secondary data for the dynamic model of profit of residential projects development

\begin{tabular}{|c|c|c|c|c|}
\hline No. & Profit factor & Variable & Value & Reference \\
\hline 1 & $\begin{array}{l}\text { Urban } \\
\text { population }\end{array}$ & $\begin{array}{l}\text { Urban population } \\
\text { Number of households }\end{array}$ & $\begin{array}{l}7,981,900 \text { persons } \\
1,005,475 \text { households }\end{array}$ & $\begin{array}{l}\text { GSO }(2015 a) \\
\text { GSO }(2015 a)\end{array}$ \\
\hline \multirow[t]{2}{*}{2} & \multirow[t]{2}{*}{ Buyer capacity } & Home ownership rate & $96 \%$ & GSO (2015a) \\
\hline & & \begin{tabular}{|l} 
Household income \\
High income \\
Medium income \\
Low income
\end{tabular} & $\begin{array}{l}\text { 9,375 - 24,000 USD/year } \\
7375 \text { - 9,374 USD/year } \\
1,475 \text { - 7374 USD/year }\end{array}$ & $\begin{array}{l}\text { General Statistics Office of Vietnam [GSO] } \\
\text { (2015b), W\&S (2016) }\end{array}$ \\
\hline \multirow[t]{3}{*}{3} & \multirow[t]{3}{*}{$\begin{array}{l}\text { Housing } \\
\text { supply }\end{array}$} & $\begin{array}{r}\text { Housing stock } \\
\text { Type-A houses } \\
\text { Type-B houses } \\
\text { Type-C houses }\end{array}$ & $\begin{array}{l}2,020 \text { houses } \\
6,900 \text { houses } \\
10,080 \text { houses }\end{array}$ & Savills (2015) \\
\hline & & Housing presale & $20 \%$ maximum & Ministry of Justice of Vietnam [MOJ] (2010) \\
\hline & & $\begin{array}{r}\text { Housing supply } \\
\text { Type-A houses } \\
\text { Type-B houses } \\
\text { Type-C houses }\end{array}$ & $\begin{array}{l}1,753 \text { houses } \\
5,737 \text { houses } \\
8,430 \text { houses }\end{array}$ & Savills (2015) \\
\hline \multirow[t]{3}{*}{4} & \multirow[t]{3}{*}{$\begin{array}{l}\text { Housing } \\
\text { economics }\end{array}$} & $\begin{array}{r}\text { House price } \\
\text { Type-A houses } \\
\text { Type-B houses } \\
\text { Type-C houses }\end{array}$ & $\begin{array}{l}145,000 \text { USD } \\
87,500 \text { USD } \\
34,700 \text { USD }\end{array}$ & $\begin{array}{l}\text { Ministry of Construction of Vietnam [MOC] } \\
\text { (2008), Savills (2015) }\end{array}$ \\
\hline & & $\begin{array}{r}\text { Construction cost } \\
\text { Type-A houses } \\
\text { Type-B houses } \\
\text { Type-C houses }\end{array}$ & $\begin{array}{l}838 \mathrm{USD} / \mathrm{m}^{2} \\
619 \mathrm{USD} / \mathrm{m}^{2} \\
364 \mathrm{USD} / \mathrm{m}^{2}\end{array}$ & $\begin{array}{l}\text { Ngoc (2014), Ministry of Construction of } \\
\text { Vietnam [MOC] (2016) }\end{array}$ \\
\hline & & $\begin{array}{c}\text { Land and consultant cost } \\
\text { Type-A houses } \\
\text { Type-B houses } \\
\text { Type- } C \text { houses }\end{array}$ & $\begin{array}{l}302 \mathrm{USD} / \mathrm{m}^{2} \\
223 \mathrm{USD} / \mathrm{m}^{2} \\
131 \mathrm{USD} / \mathrm{m}^{2}\end{array}$ & Ngoc (2014), MOC (2016) \\
\hline
\end{tabular}


End of Table 3

\begin{tabular}{|c|c|c|c|c|}
\hline No. & Profit factor & Variable & Value & Reference \\
\hline 4 & $\begin{array}{l}\text { Housing } \\
\text { economics }\end{array}$ & $\begin{array}{r}\text { Taxes and fees } \\
\text { Type-A houses } \\
\text { Type-B houses } \\
\text { Type-C houses }\end{array}$ & $\begin{array}{l}84 \mathrm{USD} / \mathrm{m}^{2} \\
62 \mathrm{USD} / \mathrm{m}^{2} \\
36 \mathrm{USD} / \mathrm{m}^{2}\end{array}$ & Ngoc (2014), MOC (2016) \\
\hline \multirow[t]{4}{*}{5} & \multirow{4}{*}{$\begin{array}{l}\text { Housing } \\
\text { finance }\end{array}$} & Housing loan interest rate & $6.50 \%$ & State Bank of Vietnam [SBV] (2016) \\
\hline & & $\begin{array}{l}\text { Construction loan interest } \\
\text { rate }\end{array}$ & $7.60 \%$ & SBV (2016) \\
\hline & & Debt to equity ratio & $80 \%$ maximum & MOJ (2010) \\
\hline & & Payment period & 25 years & Un-Habitat (2014) \\
\hline
\end{tabular}

a home ownership rate of $96 \%$. Savills (2015) stated that the total housing supply in 2014 was approximately 15,920 units, and that 19,000 units of houses were stocked in 2014.

Primary data are also collected through interviews with senior managers of real estate companies in Ho Chi Minh City, Vietnam. The interviewees have experiences in a number of real estate projects, and are involved in decision making regarding profit enhancement. They suggested that the debt to equity ratio should be around $60 \%$, the down payment should normally be set at $30 \%$ of a house price, and an additional fee of project development is approximately $10 \%$ of a construction cost.

The five key factors and their associated variables are used, together with primary and secondary data, to develop a dynamic model of profit of residential projects, utilizing an SD modeling technique.

\section{Dynamic model of profit of residential projects}

The dynamic model of profit of residential projects in Ho Chi Minh City, Vietnam, consists of six sectors, including 1) the Urban Population, 2) Buyer Capacity, 3) Housing Supply, 4) Housing Economics, 5) Housing Finance, and
6) Profit sectors (see Figure 2). Full terms of abbreviations are listed in the Appendix section.

\subsection{Urban population sector}

Ho et al. (2010) stated that changes in population (UrPo) affect housing demand. According to the GSO (2015a), the population in Ho Chi Minh City increases by $2 \%$ per year $(P I R a)$, with an average of four members in a family $(\mathrm{NoMe})$. With smaller-sized families, housing demand tends to increase. In the Urban Population sector, housing needs per year $(\mathrm{NeHN})$ are calculated by summing initial (IniHN), current $(\mathrm{CuHN})$, and left-over housing needs $(L O v N e)$ [see Eq. (1)]. The IniHN variable is the housing needs in the initial year of the model simulation, which is set at 79,819 units in this study. The CuHN variable is the current housing needs, which is calculated from the number of new families ( $\mathrm{NoFi}$ ) each year, multiplied by the home ownership rate $(\mathrm{HoOR})$ [see Eq. (2)]. The $L O v N e$ variable is the housing needs in previous years that were not fulfilled due to insufficient supply. It is the accumulated housing needs minus housing transactions (HoTr) [see Eq. (3)].

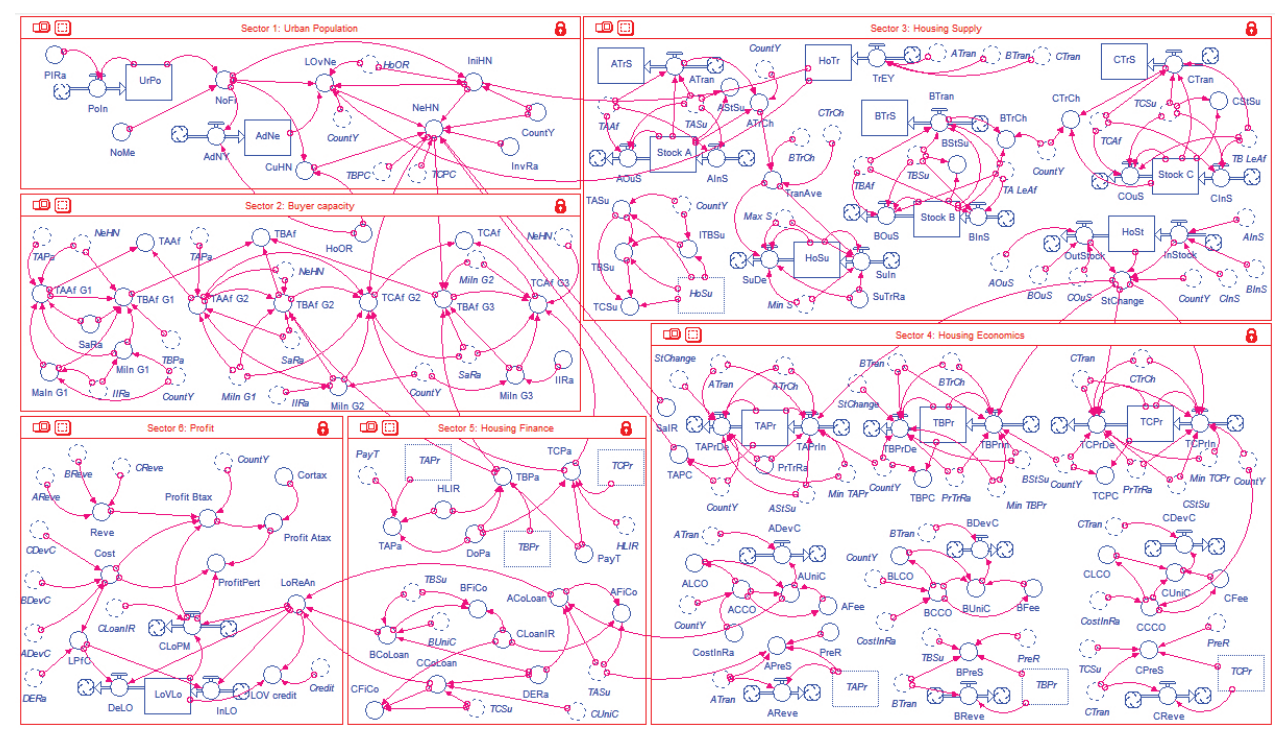

Figure 2. Dynamic model of profit of residential projects 


$$
\begin{aligned}
& N e H N=\operatorname{IF}(\text { Count } Y=0) \operatorname{THEN}(\operatorname{IniHN}) \text { ELSE } \\
& \operatorname{IF}(\operatorname{MEAN}(\text { TAPC, TBPC, TCPC })>\text { SaIR }) \\
& \operatorname{THEN}(1+\operatorname{InvRa}) \times(\operatorname{IniHN}+\mathrm{CuHN}+L \mathrm{O} v \mathrm{Ne}) \\
& \operatorname{ELSE}(\operatorname{IniHN}+\mathrm{CuHN}+\mathrm{LOvNe}) \text {; } \\
& \mathrm{CuHN}=\mathrm{HoOR} \times(\mathrm{NoFi}-\mathrm{DELAY}(\mathrm{NoFi}, 1)) ; \\
& \text { LOvNe }=I F(\text { Count } Y=0) \text { THEN } 0 \\
& \operatorname{ELSE}((1-\mathrm{HoOR}) \times \operatorname{INIT}(\mathrm{NoFi})+\mathrm{AdNe}-\mathrm{HoTr}) \text {. }
\end{aligned}
$$

The NeHN in Eq. (1) is calculated based on three different income groups: high, medium, and low (G1, G2, and $\mathrm{G} 3$, respectively), leading to three housing segments in the market (type- $\mathrm{A},-\mathrm{B}$, and -C houses). It also relies on investment demand. This occurs when changes of house prices (TAPC, TBPC, and TCPC) in the market are more attractive than the saving rate (SaIR) (Ngoc, 2014; Savills, 2015).

\subsection{Buyer capacity sector}

Buyer capacity is defined as the housing needs of each income group that can be afforded. In this study, the percentage of the three income groups are $20 \%, 20 \%$, and $60 \%$ of housing needs, respectively (GSO, 2015b; W\&S, 2016). The affordability of each income group (G1, G2, and G3) is different with different house types (type-A, -B, and -C houses or high-, mid-, and low-end houses, respectively). In other words, the affordability of each house type (TAAf, $T B A f$, and $T C A f$ ) is calculated from: 1 ) housing needs per year $(\mathrm{NeHN}), 2)$ saving amount of each income group, and 3 ) annual payment of the three house types (TAPa, TBPa, and $T C P a$ ). Eq. (4), for example, explains the affordability of the G1 group to purchase type-A houses (TAAfG1). If the annual payment of type-A houses (TAPa) falls in the income range of the G1 group (from minimum, MiIn G1, to maximum, MaIn G1, income), households of the G1 group can afford to purchase type-A houses.

$$
\begin{aligned}
& \text { TAAfG } 1=\operatorname{IF}(\text { TAPa } \geq \text { MaIn G1 } \times \text { SaRa }) \\
& \text { THEN }(0.05 \times 0.20 \times \text { NeHN }) \\
& \text { ESLE IF }(\text { TAPa } \geq \text { MiIn G1 } \times \text { SaRa })
\end{aligned}
$$

THEN $0.01 \times N e H N\left(\frac{0.19 \times N e H N \times(\mathrm{MaIn} \mathrm{G} 1 \times \mathrm{SaRa}-\mathrm{TAPa})}{\mathrm{MaIn} \mathrm{G} 1 \times \mathrm{SaRa}-\mathrm{MiIn} \mathrm{G} 1 \times \mathrm{SaRa}}\right)$

$$
\operatorname{ELSE}(0.20 \times \mathrm{NeHN})) \text {. }
$$

The households of the G1 group that have a lower saving amount than the TAPa of type-A houses will consider purchasing lower house types, i.e. type-B houses (TBAfG1) [see Eq. (5)].

$$
\begin{aligned}
& \text { TBAfG1 }=\text { IF }(\text { TBPa } \geq \text { MaIn G1 } \times \text { SaRa }) \\
& \text { THEN0 ELSE IF }(\mathrm{TBPa} \geq \text { MiIn G1 } \times \text { SaRa }) \\
& \text { THEN IF }(\text { TAAfG } 1 \geq \mathrm{NeHN} \times 0.2) \text { THEN0 ELSE }
\end{aligned}
$$

$$
\begin{aligned}
& \left(\frac{0.20 \times \mathrm{NeHN} \times(\mathrm{MaIn} \mathrm{G} 1 \times \mathrm{SaRa}-\mathrm{TBPa})}{\mathrm{MaIn} \mathrm{G} 1 \times \mathrm{SaRa}-\mathrm{MiIn} \mathrm{G} 1 \times \mathrm{SaRa}}-\mathrm{TAAfG} 1\right) \\
& \text { ELSE IF }(\mathrm{TAAfG} 1 \geq \mathrm{NeHN} \times 0.2) \\
& \text { THEN } 0 \text { ELSE }(0.2 \times \mathrm{NeHN}-\mathrm{TAAfG} 1) .
\end{aligned}
$$

\subsection{Housing supply sector}

The supplied proportions of type-A, -B, and -C houses (TASu, TBSu, and TCSu) in the initial year are $10 \%, 20 \%$, and $70 \%$ of the total supplied amount $(\mathrm{HoSu})$, with increasing rates of type-A and -B houses of $1 \%$ and $4 \%$ per year, respectively (Savills, 2015). The increasing amount of type-C houses, however, depends on the total supplied amount and the amount of type-A and -B houses in each year. In this study, the maximum amount of type-A houses is at $28 \%$, and the minimum amount of type-C houses is at $17 \%$ of the total houses supplied to support the low-income household group (Savills, 2015) [see Eqs. (6) - (8)]. $\mathrm{TASu}=\operatorname{MIN}(0.28 \times \operatorname{HoSu}, \operatorname{HoSu} \times(0.10+\operatorname{Count} \mathrm{Y} \times 0.01))$;

$$
\mathrm{TBSu}=\mathrm{IF} 0.83 \times \mathrm{HoSu}<(\mathrm{TASu}+\mathrm{ITBSu})
$$

$\operatorname{THEN}(0.83 \times \mathrm{HoSu}-\mathrm{TASu})$ ELSE ITBSu ;

$\mathrm{TCSu}=\operatorname{MAX}(\mathrm{HoSu}-\mathrm{TASu}-\mathrm{TBSu}, 0.17 \times \mathrm{HoSu})$.

Transactions of each house type (ATran, BTran, and CTran) depend on housing stocks (Stock $A$, Stock B, and Stock C), housing supplies (TASu, TBSu, and TCSu), and affordability of each house type (TAAf, TBAf, and TCAf) [see Eqs. (9) - (11)]. In Eq. (9), if the type-A affordability (TAAf) is less than its supplied amount, then the ATran is based on the TAAf. In the case that the TAAf is higher than its total supply, there is a left-over affordability of this house type (TA LeAf), so buyers consider purchasing type-B houses. The BTran, as shown in Eq. (10), therefore, depends on type-B affordability (TBAf), the left-over affordability of type-A houses (TA LeAf), and the type-B supplied amount. Similarly, the CTran in Eq. (11) depends on its affordability (TCAf), left-over affordability of type-B houses (TB LeAf), and its supplied amount each year.

$$
\begin{aligned}
& \text { ATran }=\text { IF }(\text { TAAf } \leq \text { Stock A + TASu }) \\
& \text { THEN TAAf ELSE }(\text { Stock A + TASu }) ; \\
& \text { BTran = IF }(\text { TBAf + TA LeAf }) \leq(\text { Stock B + TBSu }) \\
& \text { THEN }(\text { TBAf + TA LeAf }) \text { ELSE }(\text { Stock B + TBSu }) ; \\
& \text { CTran = IF }(\text { TCAf + TB LeAf }) \leq(\text { Stock C + TCSu }) \\
& \text { THEN }(\text { TCAf + TB LeAf }) \text { ELSE }(\text { Stock C + TCSu }) .
\end{aligned}
$$

\subsection{Housing economics sector}

The minimum house price of each house type is calculated based on cost per square meter (AUniC, BUniC, and $C U$ $\mathrm{niC}$ ), construction loan interest rate (CLoanIR), financial cost (AFiCo, BFiCo, and $C F i C o$ ), and minimum required 
areas for type-A, $-\mathrm{B}$, and $-\mathrm{C}$ houses, which are 70,60 , and $45 \mathrm{~m}^{2}$, respectively (MOC, 2008) [see Eqs. (12) - (14)].

$$
\begin{aligned}
& \text { MinTAPr }=(\text { AUniC } \times(1+\text { CLoanIR })+\text { AFiCo }) \times 70 ; \\
& \text { MinTBPr }=(\text { BUniC } \times(1+\text { CLoanIR })+\text { BFiCo }) \times 60 ; \\
& \text { MinTCPr }=(\text { CUniC } \times(1+\text { CLoanIR })+\text { CFiCo }) \times 45 .
\end{aligned}
$$

The increase or decrease in house prices depends on housing transaction amount and house age. Chandler and Disney (2014) mentioned that a double of housing transaction results in four percent higher in house prices. Goodman and Thibodeau (1995), on the other hand, stated that the price of a 1-year old house is $6.5 \%$ lower than its original price.

\subsection{Housing finance sector}

To develop residential projects, developers borrow construction loans from banks (ACoLoan, BCoLoan, and CCoLoan). The required loans are calculated by multiplying the debt to equity ratio (DERa) with development costs. In this study, the development costs include the amount of houses supplied (TASu, TBSu, and TCSu), the cost per square meter (AUniC, BUniC, and CUniC), and the minimum required areas [see Eqs. (15) - (17)].

$$
\begin{aligned}
& \text { ACoLoan }=\mathrm{TASu} \times \mathrm{AUniC} \times 70 \times \mathrm{DERa} \\
& \mathrm{BCoLoan}=\mathrm{TBSu} \times \mathrm{BUniC} \times 60 \times \mathrm{DERa} ; \\
& \mathrm{CCoLoan}=\mathrm{TCSu} \times \mathrm{CUniC} \times 45 \times \mathrm{DERa} .
\end{aligned}
$$

Developers, thus, pay financial cost (AFiCo, BFiCo, and $C F i C o$ ) based on loan amount, loan interest rate (CLoanIR), and size of each house type [see Eqs. (18) - (20)].

$$
\begin{aligned}
& \text { AFiCo }=\mathrm{IF}(\mathrm{TASu}=0) \mathrm{THEN} 0 \\
& \operatorname{ELSE}(\mathrm{ACoLoan} \times \mathrm{CLoanIR} /(\mathrm{TASu} \times 70)) ; \\
& \mathrm{BFiCo}=\mathrm{IF}(\mathrm{TBSu}=0) \mathrm{THEN} 0 \\
& \mathrm{ELSE}(\mathrm{BCoLoan} \times \mathrm{CLoanIR} /(\mathrm{TBSu} \times 60)) ; \\
& \mathrm{CFiCo}=\mathrm{IF}(\mathrm{TCSu}=0) \mathrm{THEN} 0 \\
& \operatorname{ELSE}(\mathrm{CCoLoan} \times \text { CLoanIR } /(\mathrm{TCSu} \times 45))
\end{aligned}
$$

\subsection{Profit sector}

Total revenue (Reve) is the sum of the revenue of each house type [see Eq. (21)], while total development cost (Cost) is the sum of the development cost of each house type [see Eq. (22)]. Profit before tax (Profit Btax) is calculated by having total revenue (Reve) minuses total development cost (Cost) and construction loan payment (CLoPM) [see Eq. (23)]. The construction loan payment (CLoPM) includes current required loan (LoReAn) and left-over loan in previous years (LoVLo) multiplied by loan interest rate (CLoanIR) [see Eq. (24)]. Profit after tax
(Profit Atax) is then achieved after the corporate tax (Cortax) is paid [see Eq. (25)].

$$
\begin{aligned}
& \text { Reve }=\text { AReve }+ \text { BReve }+ \text { CReve } \\
& \text { Cost = ADevC }+ \text { BDevC }+ \text { CDevC } ; \\
& \text { Profit Btax = IF }(\text { CountY =0)THEN0 ELSE } \\
& \text { (HISTORY (Reve, CountY) - } \\
& \text { HISTORY (Cost, CountY) - } \\
& \text { HISTORY (CLoPM, CountY }) \text {; } \\
& \text { CLoPM = (LoReAn }+ \text { LoVLo }) \times \text { CLoanIR; } \\
& \text { Profit Atax = Profit Btax } \times(1-\text { Cortax }) .
\end{aligned}
$$

\section{Model validation}

To validate the developed dynamic model, the model is tested with structure and behavior tests (Barlas et al., 2007). The structure test assures that model structure agrees with relationships existing in the real-world. This validity test consists of the structure confirmation, parameter confirmation, and dimensional consistency tests (Barlas et al., 2007).

- Structure Confirmation Test: The dynamic model in this study is developed based on a number of reliable sources, including textbooks, annual reports, proceedings, and international journal papers, such as the Journal of Regional Science, Fiscal Studies, and Journal of Housing Research (Goodman \& Thibodeau, 1995; Gilbert, 2002; Beeghley, 2004; Hwang \& Quigley, 2006; Barlas et al., 2007; Chandler \& Disney, 2014; Nguyen \& Chinda, 2018). These, thus, validate the structure of the model.

- Parameter Confirmation Test: The parameters in this study are explored from several sources to create meaningful estimation. For example, information regarding demographic, housing, and economic parameters derived from the General Statistics Office of Vietnam (GSO 2015a; 2015b), State Bank of Vietnam (SBV, 2016), and well-known consulting companies in Vietnam (Savills, 2015; W\&S, 2016).

- Dimensional Consistency Test: Units in the developed model are consistent, such as US dollars for money, and units for houses supplied, stocked, and transacted.

The behavior test, on the other hand, assesses whether the model and real system have the same behavior patterns (Barlas et al., 2007; Zhao et al., 2011; Doan \& Chinda, 2016). The simulation results, in this study, are found to be consistent with studies in Malaysia (Mahmood \& Zakaria, 2007), United States (David, 2015), and China (YCharts, 2016), thus, confirming the utilization of the developed model in real practices (see Tables 4 and 5). 
Table 4. Simulation results

\begin{tabular}{|c|c|c|c|c|}
\hline Year & $\begin{array}{c}\text { Revenue } \\
\left(\mathrm{x} 10^{6} \text { USD }\right)\end{array}$ & $\begin{array}{c}\text { Cost } \\
\left(\mathrm{x} 10^{6} \text { USD }\right)\end{array}$ & $\begin{array}{c}\text { Profit after tax } \\
\left(\mathrm{x} 10^{6} \text { USD }\right)\end{array}$ & $\begin{array}{c}\text { Profit } \\
\text { margin } \\
(\%)\end{array}$ \\
\hline 1 & 115.71 & 67.45 & 17.82 & 19 \\
\hline 2 & 748.43 & 493.59 & 161.17 & 29 \\
\hline 3 & $1,879.34$ & $1,251.73$ & 443.18 & 33 \\
\hline 4 & $2,625.72$ & $1,710.88$ & 644.13 & 35 \\
\hline 5 & $2,542.83$ & $1,643.95$ & 598.22 & 33 \\
\hline 6 & $2,402.46$ & $1,550.48$ & 541.59 & 31 \\
\hline 7 & $2,874.30$ & $1,827.84$ & 674.34 & 33 \\
\hline 8 & $3,347.66$ & $2,119.62$ & 806.77 & 34 \\
\hline 9 & $3,821.88$ & $2,371.97$ & 983.61 & 38 \\
\hline 10 & $5,119.08$ & $3,176.85$ & $1,383.35$ & 41 \\
\hline 11 & $5,983.15$ & $3,760.16$ & $1,624.84$ & 41 \\
\hline 12 & $6,163.23$ & $3,937.14$ & $1,652.49$ & 40 \\
\hline 13 & $6,257.01$ & $4,009.68$ & $1,674.38$ & 40 \\
\hline 14 & $6,608.26$ & $4,246.18$ & $1,734.76$ & 39 \\
\hline 15 & $6,460.21$ & $4,156.56$ & $1,678.47$ & 38 \\
\hline 16 & $5,989.26$ & $3,880.49$ & $1,516.08$ & 37 \\
\hline 17 & $5,684.65$ & $3,731.08$ & $1,388.15$ & 35 \\
\hline 18 & $5,590.50$ & $3,719.31$ & $1,323.51$ & 34 \\
\hline 19 & $5,622.79$ & $3,832.45$ & $1,263.52$ & 31 \\
\hline 20 & $5,601.98$ & $3,848.10$ & $1,243.19$ & 31 \\
\hline
\end{tabular}

Table 5. Profit margin of residential projects in different countries

\begin{tabular}{|c|l|c|c|c|l|}
\hline \multirow{2}{*}{ No. } & \multirow{2}{*}{ Country } & \multicolumn{3}{|c|}{ Profit (\%) } & \multirow{2}{*}{ Reference } \\
\cline { 3 - 5 } & & Max & Min & Average & \\
\hline 1 & Vietnam & 41 & 19 & 35 & This study \\
\hline 2 & China & 53 & 15 & 30 & YCharts (2016) \\
\hline 3 & Malaysia & 32 & 10 & 21 & $\begin{array}{l}\text { Mahmood and } \\
\text { Zakaria (2007) }\end{array}$ \\
\hline 4 & USA & 35 & 14 & 24 & David (2015) \\
\hline
\end{tabular}

\section{Simulation results}

The dynamic model of profit of residential projects is simulated for 20 years, imitating the current period of the Vietnamese residential market. This simulation period is consistent with a number of real estate-related studies (Huang \& Wang, 2005; Barlas et al., 2007; Ho et al., 2010; Amini et al., 2013). The simulation results (see Table 4) show that during the first four years, profit increases steadily, as more houses are purchased with higher house prices due to higher household income. In year 5, however, house prices, especially for type-A houses, become very high that households cannot afford to purchase them. This, in turn, causes lower affordability, leading to price reduction in year 6 . After that, the profit starts to increase again as households are able to purchase houses with an allowable budget. This increasing trend continues until house prices become so high that households cannot afford a house, and the profit reduces again.

The simulation results also show that the maximum, minimum, and average profits of residential projects are $41 \%, 19 \%$, and $35 \%$ over the 20 -year period, respectively. These are consistent with the study results in many developing (China and Malaysia) and developed countries (United States) (see Table 5). Though profits after tax in the first two years are low, the simulation results confirm that the residential real estate market in Ho Chi Minh City, Vietnam, is a promising and lucrative market in the long term.

\section{Scenario analysis}

To further examine alternative strategies to enhance profit of residential projects, a scenario analysis is performed with four key variables, including the payment period, down payment, house price, and debt to equity ratio.

\subsection{Scenario 1: payment period}

There are four payment periods available in the Vietnamese residential market, including 10-, 15-, 20-, and 25-year periods (Nhien, 2016). The longer payment period results in smaller annual payment. This leads to higher buyer affordability and housing transaction, resulting in more profit. Figure 3 shows that the 25 -year payment plan helps developers to earn the highest profit in the long term.

Profit after tax (x106 USD)

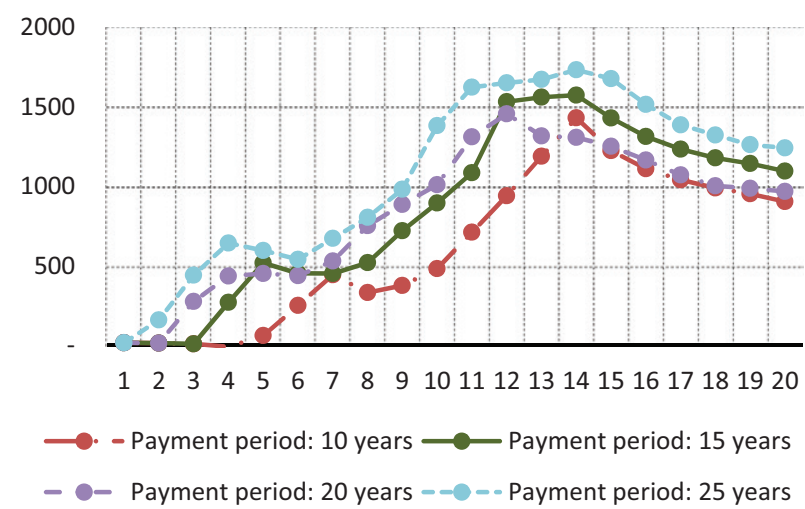

Figure 3. Scenario analysis results when payment period is changed

\subsection{Scenario 2: down payment}

In this study, four cases of down payment amount are examined, including $0 \%, 10 \%, 20 \%$, and $30 \%$ of the total payment (Nhien, 2016). It is expected that developers earn higher profit with higher down payment, as lower construction loan and financial costs are achieved. The 30\%-down payment, therefore, brings the highest profit to developers in the long term (see Figure 4). Households, however, might not be able to afford high amount of down payment, so a combination of different down payment amount of each house type might be considered in future studies. 
Profit after $\operatorname{tax}\left(x 10^{6}\right.$ USD)

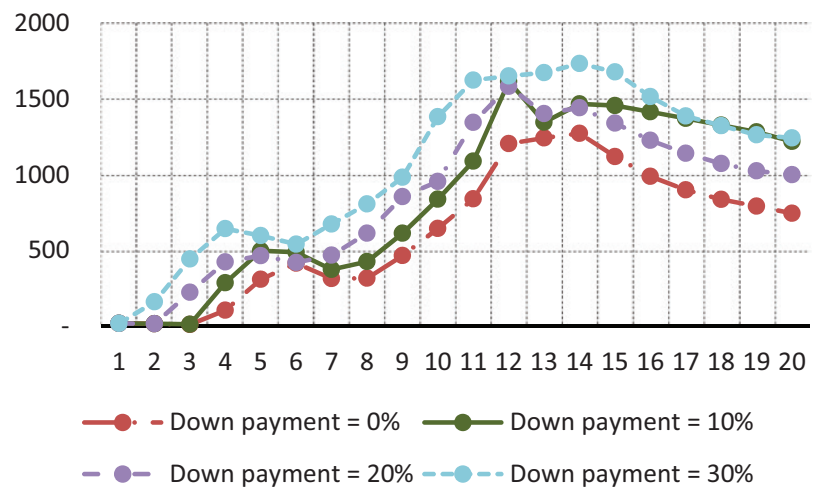

Figure 4. Scenario analysis results when down payment is changed

\subsection{Scenario 3: change in house price}

The profit of residential projects is affected by different house prices. In this study, house prices change from normal to the highest price, reflecting a booming economic period. According to Ngoc (2014), the highest increasing rate in house price is $16 \%$. Simulation results reveal that developers earn more profit with higher house prices in the long term (see Figure 5). However, developers should not raise house price in the first four years due to low affordability, especially for the G3-income group. This is consistent with Le (2015) that the type-C house segment (low-end houses) is an attractive housing segment for $\mathrm{Vi}$ etnam in the next five years.

\subsection{Scenario 4: debt to equity ratio}

According to the MOJ (2010), developers must have a minimum equity of $20 \%$ of total development cost to develop a residential project. The debt to equity ratio, therefore, ranges from $0 \%$ to $80 \%$, representing no construction loan (i.e. no debt) to $80 \%$ loan from the total development cost. With a constant equity, a higher debt to equity ratio

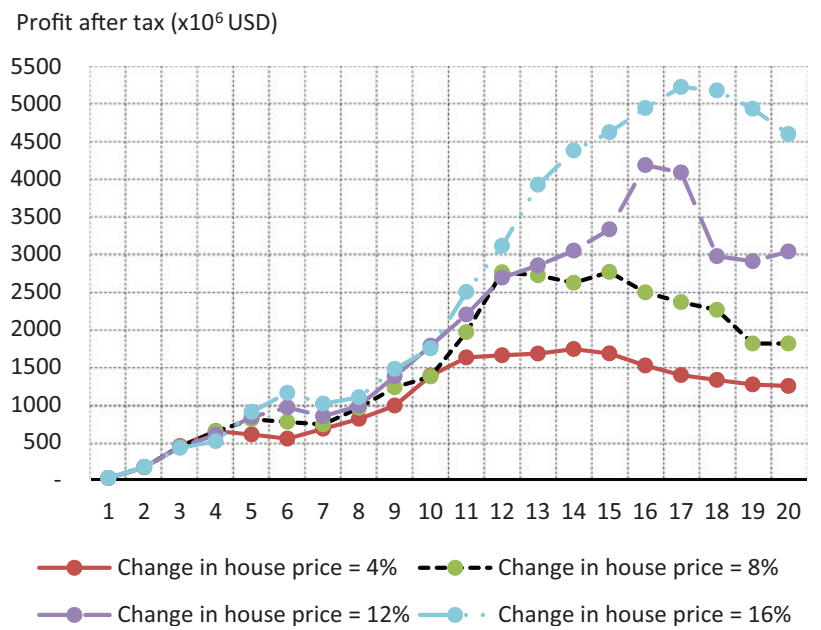

Figure 5. Scenario analysis results when house price is changed

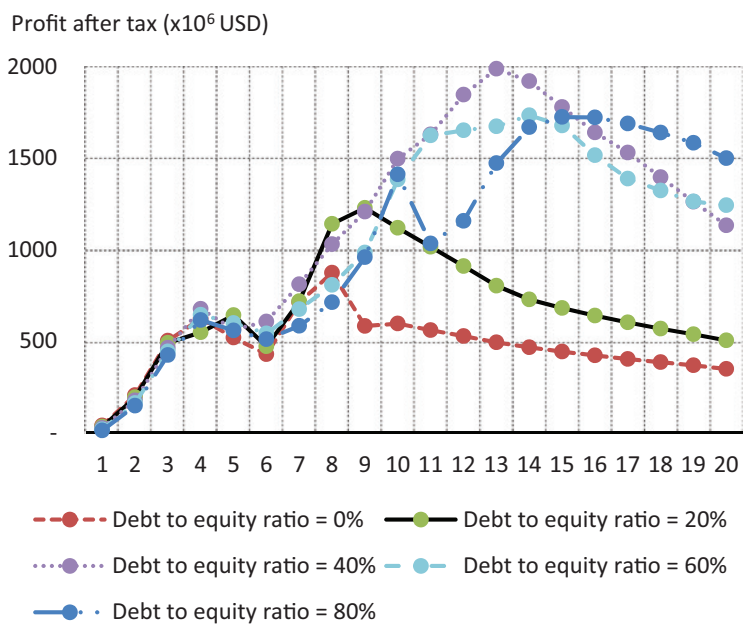

Figure 6. Scenario analysis results when debt to equity ratio is changed

results in a higher construction loan. This, however, leads to more financial cost, resulting in higher house prices. The highest debt to equity ratio (80\%), therefore, does not ensure the highest profit (see Figure 6). The results show that the most suitable debt to equity ratio is $40 \%$. This is supported by Chiang et al. (2002) that debt to equity ratio in a range of $39 \%$ to $43 \%$ helps developers to gain optimum profits.

\section{Conclusions}

Expansion of the economy and population in Ho Chi Minh City, Vietnam lead real estate companies to good opportunities to invest in more residential projects. It is, however, difficult to enhance profit of residential projects in a complex and dynamic business environment. This research study, therefore, develops a dynamic model of profit of residential projects to examine the interrelationships among key profit factors, and assist developers to better plan for profit enhancement in the long term. The developed dynamic model consists of five key profit factors, including 1) the Urban Population, 2) Buyer Capacity, 3) Housing Supply, 4) Housing Economics, and 5) Housing Finance factors.

The simulation results confirm that the residential market in Ho Chi Minh City, Vietnam, is a lucrative market, with average and highest profit margins of 35\% and $41 \%$, respectively. This is consistent with existing knowledge of other real estate markets in both developed and developing countries (Mahmood \& Zakaria, 2007; David, 2015; YCharts, 2016). Scenario analysis results suggest that a payment period of 25 years and a down payment of $30 \%$ are a good payment strategy to achieve the highest profit in the long term. It is also recommended that developers maintain the debt to equity ratio and house price in the early years to assist low-income households, and raise house price after 4 years when households have more income. 
This research study provides major contributions to the existing body of knowledge. Most studies examine interactions among key profit factors, yet feedback loops of those key factors are not considered. Due to changes in world politics and economy, developers may face difficulties to plan for profit enhancement in a dynamic environment. This study examines the key profit factors and their interactions in the long term, by considering current data, and predicting future trend comprehensively and systematically. The developed dynamic model evaluates a profit enhancement plan from a holistic point of view. This, in turn, assists developers to examine influences and relationships among key profit factors, and plan for profit enhancement in the long term. The results can also be considered as a starting point for a software development that allows developers to examine their strategies by simply inputting their available information as input data, thus making it easy and practical in real practices.

There are limitations in this study. The study is conducted based on data in Ho Chi Minh City, Vietnam. Using the model in other geographical areas, therefore, needs certain adjustments. Factors, such as competitor and location, could also be added, if needed, to reflect real situations.

The dynamic model of profit of residential projects could be used as a guideline for real estate companies to plan for better profit enhancement. Developers could also use scenario analyses to select the most appropriate strategy to be implemented in the long term, without a real implementation. This helps developers to save unnecessary costs by not actually implementing a suitable scenario. The Vietnamese government can also support developers by, for example, controlling the saving and loan interest rates, and limiting the debt to equity ratio.

\section{Acknowledgement}

This research study was granted by the Sirindhorn International Institute of Technology (SIIT), Thammasat University, Thailand under the Excellent Foreign Students (EFS) scholarship.

\section{References}

Amini, Y., Kasmaei, S. J., Sharifan, G., Eslamifar, G., \& Aghdaei, A. (2013, 21-25 July). A system dynamics approach to clarify the impacts of state loans on real estate market in Iran. Proceedings of the 31st International Conference of the System Dynamics Society. Cambridge, Massachusetts, USA.

Barlas, Y., Ozgun, O., \& Ozbas, B. (2007, 29 July-2 August). Modeling of real estate price oscillations in Istanbul. Proceedings of the 25th International Conference of the System Dynamics Society. Sloan School of Management, MIT, Boston, USA, 2007.

Beeghley, L. (2004). Structure of social stratification in the United States (4th ed.). Boston: Allyn \& Bacon.

Borowiecki, K. J. (2009). The determinants of house prices and construction: an empirical investigation of the Swiss housing economy. International Real Estate Review, 12(3), 193-220.
Capelo, C., \& Dias, J. F. (2009). A system dynamics-based simulation experiment for testing mental model and performance effects of using the balanced scorecard. System Dynamics Review, 25(1), 1-34. https://doi.org/10.1002/sdr.413

Chandler, D., \& Disney, R. (2014). The housing market in the United Kingdom: effects of house price volatility on households. Fiscal Studies, 35(3), 371-394.

https://doi.org/10.1111/j.1475-5890.2014.12034.x

Chiang, Y. H., Chan, P. C. A., \& Hui, E. C. M. (2002). Capital structure and profitability of the property and construction sectors in Hong Kong. Journal of Property Investment and Finance, 20(6), 434-453. https://doi.org/10.1108/14635780210446469

Choi, J., \& Russell, J. S. (2005). Long-term entropy and profitability change of United States public construction firms. Journal of Management in Engineering, 21(1), 17-26.

https://doi.org/10.1061/(ASCE)0742-597X(2005)21:1(17)

Clark, T. D., \& Jones, M. C. (2008). An experimental analysis of the dynamic structure and behavior of managerial support systems. System Dynamics Review, 24(2), 215-245.

https://doi.org/10.1002/sdr.401

David, W. (2015). An inside view on real estate profit margins. Property Management Insider. Retrieved from http://www. propertymanagementinsider.com/an-inside-view-on-realestate-profit-margins

Doan, D. T., \& Chinda, T. (2016). Modeling construction and demolition waste recycling program in Bangkok: benefit and cost analysis. Journal of Construction Engineering and Management, 142(12). https://doi.org/10.1061/(ASCE)CO.1943-7862.0001188

Fisher, J., Ling, D. C., \& Naranjo, A. (2009). Institutional capital flows and return dynamics in private commercial real estate markets. Real Estate Economics, 37(1), 85-116. https://doi.org/10.1111/j.1540-6229.2009.00236.x

Gerlach, S., \& Peng, W. (2005). Bank lending and property prices in Hong Kong. Journal of Banking and Finance, 29, 461-481. https://doi.org/10.1016/j.jbankfin.2004.05.015

Gilbert, D. (2002). The American class structure in an age of growing inequality (6th ed.). California: Wadsworth Publishing.

Gimpelevich, D. (2011). Simulation-based excess return model for real estate development: a practical Monte Carlo simulation-based method for quantitative risk management and project valuation for real estate development projects illustrated with a high-rise office development case study. Journal of Property Investment and Finance, 29(2), 115-144. https://doi.org/10.1108/14635781111112765

Goodman, A. C., \& Thibodeau, T. G. (1995). Age-related heteroskedasticity in hedonic house price equations. Journal of Housing Research, 6(1), 25-42.

General Statistics Office of Vietnam. (2015a). Niên giám thống $k \hat{e}$ [Statistical Yearbook of Vietnam]. GSO, Hanoi. Retrieved from http://gso.gov.vn/default.aspx?tabid=512\&idmid=5\&Ite $\mathrm{mID}=16051$ (In Vietnamese)

General Statistics Office of Vietnam. (2015b). Kết quả khảo sát mức sống dân cư Việt Nam năm 2012 [Result of the Vietnam household living standards survey 2012]. GSO, Hanoi. Retrieved from http://gso.gov.vn/default.aspx?tabid=512\&idmi $\mathrm{d}=5$ \&ItemID $=13970$ (In Vietnamese)

Ho, Y. F., Wang, H. L., \& Liu, C. C. (2010, 25-29 July). Dynamics model of housing market surveillance system for Taichung City. Proceedings of the 28th International Conference of the System Dynamics Society. Seoul, Korean.

Hou, W., Liu, X., \& Chen, D. (2011). Payment problems, cash flow and profitability of construction project: a system dynamics model. World Academy of Science, Engineering and Technology, 58, 693-699. 
Huang, F., \& Wang, F. (2005). A system for early-warning and forecasting of real estate development. Automation in Construction, 14, 333-342. https://doi.org/10.1016/j.autcon.2004.08.015

Hwang, M., \& Quigley, J. M. (2006). Economic fundamentals in local housing markets: evidence from U. S. metropolitan regions. Journal of Regional Science, 46(3), 425-453. https://doi.org/10.1111/j.1467-9787.2006.00480.x

Hwang, S., Park, M., \& Lee, H. (2013a). Dynamic analysis of the effects of mortgage-lending policies in a real estate market. Mathematical and Computer Modelling, 57, 2106-2120. https://doi.org/10.1016/j.mcm.2011.06.023

Hwang, S., Park, M., Lee, H., Lee, S., \& Kim, H. (2013b). Dynamic feasibility analysis of the housing supply strategies in a recession: Korean housing market. Journal of Construction Engineering and Management, 139(2), 148-160.

https://doi.org/10.1061/(ASCE)CO.1943-7862.0000577

Kang, Y., \& Bai, Y. (2014). Research on capital structure and profitability of real estate listed companies in the post financial crisis era. Proceeding of the 2014 International Conference on Construction and Real Estate Management (pp. 989994). American Society of Civil Engineers, Kunming, China. https://doi.org/10.1061/9780784413777.116

Kim, E., \& Yang, W. (2006). Profitability of office rental market in Seoul: an application of simultaneous structural equations. Real Estate Economics, 34(1), 157-171. https://doi.org/10.1111/j.1540-6229.2006.00163.x

Kwoun, M., Lee, S., Kim, J., \& Kim, J. (2013). Dynamic cycles of unsold new housing stocks, investment in housing, and housing supply-demand. Mathematical and Computer Modelling, 57, 2094-2105. https://doi.org/10.1016/j.mcm.2011.08.005

Le, V. (2015). Nhà già rẻ Sài Gòn vẫn hấp dẫn trong 5 năm tới [Saigon cheap houses are still attractive within the next 5 years]. Vnexpress. Retrieved from http://kinhdoanh.vnexpress.net/tin-tuc/bat-dong-san/nha-gia-re-sai-gon-van-hapdan-trong-5-nam-toi-3220548.html (In Vietnamese)

Ling, D. C., \& Naranjo, A. (2003). The dynamics of REIT capital flows and returns. Real Estate Economics, 31(3), 405-434. https://doi.org/10.1111/1540-6229.00071

Liow, K. H. (2010). Firm value, growth, profitability, and capital structure of listed real estate companies: an international perspective. Journal of Property Research, 27(2), 119-146. https://doi.org/10.1080/09599916.2010.500459

Liu, S., \& Wang, C. (2008). Resource-constrained construction project scheduling model for profit maximization considering cash flow. Automation in Construction, 17, 966-974. https://doi.org/10.1016/j.autcon.2008.04.006

Mahmood, W. M. W., \& Zakaria, R. (2007). Profitability and capital structure of the property and construction sectors in Malaysia. Pacific Rim Property Research Journal, 13(1), 92105. https://doi.org/10.1080/14445921.2007.11104224

Ministry of Justice of Vietnam. (2010). Nghị định 71/2010/NDCP [Decree 71/2010/ND-CP]. MOJ, Hanoi. Retrieved from http://moj.gov.vn/vbpq/lists/vn\%20bn\%20php\%20lut/view_ detail.aspx?itemid=25426 (In Vietnamese)

Ministry of Construction of Vietnam. (2008). Thông tư 14/2008/TT-BXD [Circulation 14/2008/TT-BXD]. MOC, Hanoi. Retrieved from http://vanban.chinhphu.vn/portal/ page/portal/chinhphu/hethongvanban?class_id=1\&mode $=$ detail\&document_id=67938 (In Vietnamese)

Ministry of Construction of Vietnam. (2016). Suất vốn đấu tu xây dựng công trình [Investment unit cost]. MOC, Hanoi. Retrieved from http://www.xaydung.gov.vn/c/document_library/get_file?p_l_id=10499\&folderId=29703\&name $=47403$ (In Vietnamese)
Morri, G., \& Cristanziani, F. (2009). What determines the capital structure of real estate companies?: An analysis of the EPRA/NAREIT Europe index. Journal of Property Investment and Finance. 27(4), 318-372. https://doi.org/10.1108/14635780910972288

Ngoc, L.T. (2014). Residential real estate bubbles in Ho Chi Minh City (PhD thesis). The Ho Chi Minh City Banking University, Vietnam. Retrieved from http://buh.edu.vn/nguoi-hoc/ sau-dai-hoc/luan-van-luan-an.html (in Vietnamese)

Nguyen, N. H., \& Chinda, T. (2018). Interrelationships among key profit factors of Vietnamese residential projects using structural equation modelling. Songklanakarin. Journal of Science and Technology, 40(2), 474-481.

Nhien, A. (2016). Lãi suất vay thế chấp của ngân hàng nào đang thấp nhất [Which banks have the lowest mortgage interest rates?]. Life and Law newspaper, Vietnam. Retrieved from http://www.doisongphapluat.com/kinh-doanh/bat-dong-san/ lai-suat-vay-the-chap-cua-ngan-hang-nao-dang-thap-nhata89294.html (In Vietnamese)

Park, M., Lee, M., Lee, H., \& Hwang, S. (2010). Boost, control, or both of Korean housing market: 831 countermeasures. Journal of Construction Engineering and Management, 136(6), 693701. https://doi.org/10.1061/(ASCE)CO.1943-7862.0000159

Park, M., Kim, Y., Lee, H., Han, S., \& Hwang, S. (2013). Modeling the dynamics of urban development project: focusing on self-sufficient city development. Journal of Mathematical and Computing Modelling, 57, 2082-2093.

https://doi.org/10.1016/j.mcm.2011.05.058

Rehring, C., \& Sebastian, S. (2011). Dynamics of commercial real estate asset markets, return volatility and the investment horizon. Journal of Property Research, 28(4), 291-315.

https://doi.org/10.1080/09599916.2011.596943

Saeed, K., \& Brooke, K. (1996). Contract design for profitability in macro-engineering projects. System Dynamics Review, 12(3), 235-246. https://doi.org/10.1002/(SICI)10991727(199623)12:3<235::AID-SDR104>3.0.CO;2-Y

Savills. (2015). Ho Chi Minh City apartment for sale briefing. Savills Vietnam. Retrieved from http://www.savills.com.vn/ research/residential-sales-research.aspx

State Bank of Vietnam [SBV]. (2016). Thông tin hoạt động ngân hàng trong tuần [Weekly information on banking operations]. SBV, Hanoi. Retrieved from http://www. sbv.gov.vn/webcenter/portal/en/home/sm/prerel/wiobo? afrLoop=6069891216834626\#\%40\%3F_afrLoop\%3D606989121 6834626\%26centerWidth\%3D80\%2525\%26leftWidth\%3D20\% 2525\%26rightWidth\%3D0\%2525\%26showFooter\%3Dfalse $\% 2$ 6showHeader\%3Dfalse\%26_adf.ctrl-state\%3D1cwvt9ugyz_289 (In Vietnamese)

Tsolas, I. E. (2011). Modelling profitability and effectiveness of Greek-listed construction firms: an integrated DEA and ratio analysis. Construction Management and Economics, 29, 795807. https://doi.org/10.1080/01446193.2011.610330

Un-Habitat. (2014). Vietnam housing sector profile. Hanoi: UnHabitat.

W\&S. (2016). Report on housing in Hanoi and Ho Chi Minh City. W\&S Vietnam. Retrieved from https://vinaresearch.jp/ sample/voluntary_surveys/detail.php?ID=54

YCharts. (2016). China HGS real estate profit margin. Integrity Wealth Management. Retrieved from https://ycharts.com/ companies/HGSH/profit_margin

Zhao, W., Ren, H., \& Rotter, V. S. (2011). A system dynamics model for evaluating the alternative of type in construction and demolition waste recycling center - the case of Chongqing, China. Resources, Conservation and Recycling, 55, 933944. https://doi.org/10.1016/j.resconrec.2011.04.011 


\section{Appendix}

ACoLoan Type-A house construction loan;

ADevC Type-A house development;

AdNe Additional housing needs;

AdNY Additional housing needs each year;

AInS Inflow of type-A house stocks;

AOuS Outflow of type-A house stocks;

APreS Presale of type-A houses;

AReve Revenue of type-A houses;

ATran Type-A house transaction;

ATrCh Change in type-A house transaction;

ATrS Stock of type-A house transaction;

BCoLoan Type-B house construction loan;

BDevC Type-B house development cost;

BInS Inflow of type-B house stocks;

BOuS Outflow of type-B house stocks;

BPreS Presale of type-B houses;

BReve Revenue of type-B houses;

BTran Type B-house transaction;

BTrCh Change in type-B house transaction;

BTrS Stock of type-B house transaction;

CCoLoan Type-C house construction loan;

CDevC Type-C house development;

CInS Inflow of type C house stocks;

CostInRa Construction cost increase ratio;

CostAve Average development cost;

CountY Counter year;

COuS Outflow of type-C house stocks;

CPreS Presale of type-C houses;

Credit Credit for housing development;

CReve Revenue of type- $C$ houses;

CTran Type-C house transaction;

$\mathrm{CTrCh} \quad$ Change in type- $\mathrm{C}$ house transaction;

CTrS Stock of type-C house transaction;

DERa Debt to equity ratio;

HoSt Total houses stocked;

HoTr Quantity of housing transaction;

ITBSu Initial type-B house supply;
InStock Inflow of housing stock;

InvRa Housing investment ratio;

MaIn G1 Max income of group 1;

MiIn G1 Min income of group 1;

MiIn G2 Min income of group 2;

MiIn G3 Min income of group 3;

OutStock Outflow of housing stock;

PoIn Population increase each year;

PreS Housing presales;

StChange Housing stock change;

SuDe Housing supply decrease;

SuIn Housing supply increase;

TAAf Type A house affordability;

TAAf G1 Type-A house affordability of G1;

TAAf G2 Type-A house affordability of G2;

TAPC Change in type A house price;

TAPrDe Type-A house price decrease;

TAPrIn Type-A house price increase;

TASu Type-A house supply;

TBAf Type-B house affordability;

TBAf G1 Type-B house affordability of G1;

TBAf G2 Type-B house affordability of G2;

TBAf G3 Type-B house affordability of G3;

TBPC Change in type- $B$ house price;

TBPrDe Type-B house price decrease;

TBPrIn Type-B house price increase;

TBSu Type-B house supply;

TCAf Type-C house affordability;

TCAf G2 Type-C house affordability of G2;

TCAf G3 Type-C house affordability of G3;

TCPC Change of type-C house price;

TCPrDe Type-C house price decrease;

TCPrIn Type-C house price increase;

TCSu Type-C house supply;

TranAve Transaction change;

TrEY Annual housing transaction. 